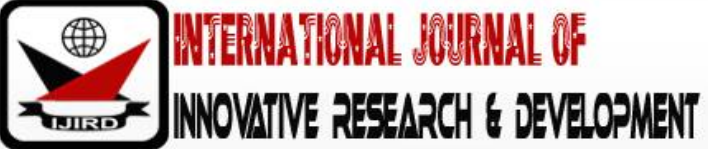

ISSN 2278 - 0211 (Online)

\section{Strategies for Recuperating the Competence of Informal Land Delivery Channels}

\begin{tabular}{|c|}
\hline Austine Audu Danladi \\
Area Town Planning Officer \\
Department Name of Development Control \\
Nasarawa State Urban Development Board, \\
Daniel Adamu \\
Lecturer, Department of Urban and Regional Planning \\
Nasarawa State University Keffi
\end{tabular}

\begin{abstract}
:
There is a mounting accord in study that informal land has contributed the bigger part of urban land for housing stipulation. The informal land system as flexible as they appear have a process via which transactions are carried out. These processes through which household owners access land for housing are not accidental but are structured and regulated by some form of social ordering. Notwithstanding, despite their major contributions to providing residential housing, several shortcomings such as tenure insecurity, uncoordinated development etc, are some of the resultant outcomes of the system. This paper therefore, with the aid of data obtained through primary and secondary sources which were analyzed, and presented in matrixes explains the strategies that are required to improving the workings of informal land institutions in Karu the gate city as a reference to other Nigeria cities. 310 questionnaires were distributed amongst household owners using Likert scale. This paper identified legal recognition of the informal land delivery sector, introduction of local land managers at district levels, guided development, transparency and accountability and assessment. Despite some shortcoming associated with informal land delivery, this paper has established that with the strategies proposed such challenges can be checkmated. However, the paper concludes that state should not be seen as the sole umpire in charge of controlling urban land markets but alternative institutions, in this case, formal and informal be allowed manage and regulate urban land market to be supported by law
\end{abstract}

Keywords: Strategies, land, informal land delivery, improvement, efficiency

\section{Introduction}

Land is a concrete, hard-wearing and inextensible item, and a foundation for economic progress. Land can be nationalized society-owned or private owned. Private-owned land is frequently acquired through legacy, formal or informal acquire, and society or State donation. As affirmed by UN Habitat (2010, pp. 4-6), land rights transfer through procure is usually referred as land market because it consists of exchange of a goods (land) against capital between the seller (landowner) and the patron (land buyer) and greetings supply and demand doctrine. Land market is not stretchy because land is a finite reserve while the population is always growing particularly in urban areas of rising countries which are noticing hasty urbanization that requires huge land for a variety of purposes including housing, industry development, services, infrastructure, etc. Formal or informal are two types of land market. Land market is formal when land right relocates through buy is done in admiration with national laws and regulations governing land transfer rights: land to be sold is advertised; prices permanent and land rights transfer legitimately. Developed countries have different formal land market works dissimilar to developing countries where informal land market principally succeeds. In developing world, the formal land market works hardly due to either the lost or the slackness of laws and rules or the nonenforcement of passed laws. As a rejoinder, land is occupied through informal process that encircles bequest, informal procure, squatting, private contribution, etc (UN HABITAT, 1996, p. 239-241). Land right transfer is done vocally with an unsanctioned sale contract signed by the land merchant, the shopper and a few witnesses from either side or proof of inheritance, and not legitimately recorded. Thirkell (1996) distinguished that information on land to be sold was stretch through social set of connections or from side to side unofficial charges.

Therefore, the study on which this piece of writing is based, sought to bring insights on urban informal land delivery system, in relation to approaches that will make them competently and successfully worthwhile.

\subsection{The Concept of Informal Urban Land Delivery System}

Based on situation practices known under the umbrella term "informal" may change. It has many other names like neo-customary, quasi-customary practices, living law etc. As per UN-Habitat (2010), any land contact, transactions which 
are not documented as well as not publicly published by state officials are under such type. Necessary management embargo for formalizations have not been by informal land delivery (Antwi, 2002). It is out of scope from any kind of measurement made by government (Kironde ,1995). In this type of land delivery system, it is privately owned like through some means of occupation, influence or power etc. For urban these are actually involuntary. To match environment of urban area, it is combination of many practices, such as regular/ civil code etc. this area is very much complex in case of execution. Hence this study treats informal land delivery scheme outside any kind of formal land scheme which allocates, estrange, arbitrate land contract without any formal structure. But just like formal channel it also has a judiciary body to control land related dealings. Local government councillors, traditional leaders, chiefs, community leaders, and community and kin networks take the main part here.

\subsection{Strategies for Dealing with Informal Land Delivery System}

Gondo identified three main steps for dealing in this area, proactive in nature. Durand-Lasserve (1996) and Fourie (1997), planned other strategies: guided development and Introduction of Local Land Managers at District Levels

\subsubsection{Recognition}

Legal, policy and institutional environment where it can operate is known. This helps land controllers for adapting constructive position on these scopes. Here, principles which guide provide support of any process taking form within their burg.

\subsubsection{Awareness and Identification}

For purposeful search and scrutiny it is very helpful. List of major and minor determinants of familiarity and the provocations can be found from here.

\subsubsection{Assessment}

In land management process, it acts as an audit system. It has three types of scenario along with it: "no effect", "positive effect" and "negative effect". Degree of influence helps to quantify degree of effect. Foreseen of legal, policy and institutional scopes can be visualized from this. It is reactive nature. Proper response is being required from land management professionals (Gondo, 2008).Sample regional states in Ethiopia have been exposed by three possible responses. Two main types are i. Isolation and resistance ii. Partnerships, cooperation, and mutual problem solving

Appropriate problem solving strategy has been found by creating and ensuring collaboration and problem solving through co-operation. Parties are getting affected often face aggression and confrontation (Carlsson L., and Berkes F., 2005; Natcher et al, 2005). Pressure, disparaging denigration of land policies, exploitation and expansion of regressive climates in collaborative meetings are common indications in real life. Arranged outputs are mainly common nature of accommodative strategies. As per Gondo (2008), integrative approach which can ensure relationship with important stakeholders of land management during all time should be adapted by land managers. Helpful remarks, positive environment, good turn over in meetings are some of the positive results of such integration. This type of attitudecreates extra opportunities to grow. (1) Avoid (no action) (2) Compete / confront and (bulldozer/ law and court a.k.a coercion) (3) Accommodate, (negotiation) are the three possible types of response options. Less taxing and less controversial nature are making urban land informal delivery system more striking. This creates a transparent view. According to Perera, 1994; AlSayyad, 2000, land management process becomes successful if matters are being finished or sorted. Active and open fighting are some other alternatives here. Many challenges are there to solve this problem. To make easy of this problem of land management is the main purpose. Gondo (2008), highlighted these as concrete consequences at least in the short term. It is often elongated and soiled and cannot be eased by such provisional and inadequate strategies. Diversification of resources can be an effective way to solve this. The primary objective should be building processes at every stage, right from the acquisition of land. This also helps to smoothly evaluate as well as to monitor. Accepting a spirited approach would not affect relationship building process. Main result of this approach is always yield a win-lose situation. What is nevertheless requisite is win-win situation that can only be counterfeit via a finding the middle ground process.

\subsubsection{Guided Development}

Durand-Lasserve (1996) suggested strategy known as "Guided Development". This strategy proposes that informal stakeholders should be to be part of formal institution. This method above reveals that apart from operating informally in dealing with land management, countries are comprehensively to amalgamate them into their formal apparatus. Acknowledgement from national land policies is very important. For urban land market, acknowledgement and recognition of every informal land rights create non-conformist transaction. Local simplified land registers have become a common mandatory practice to identify regulations of local society. Formal municipal land register has registration for all agreements with security for durations. Local register has only registration for individual plots.

\subsection{Introduction of Local Land Managers at District Levels}

Fourie (1997) highlighted "Optimal land management. Actual effective recommendations are being provided by local land administrator at district levels. Partnership and cooperation are the main purpose behind this type of approach. After getting habituated change control becomes important. For effective land delivery as well as to achieve sustainability proper and efficient technical and social skills are required. After this documentation is required by Local Land controller who acts as a local-level coordinator. Planning, developing, upgrading are the most important steps to achieve sustainability. For urban management system, local controller is a key person to handle informal land delivery system. To 
work more efficiently and to achieve objective, training, resource planning, surveys of land, proper administration are being required. It is always better to use local resource because ILDS operates best on local setting. The main logic is not to underestimate ILDS but establish dual system of land delivery through mutual cooperation. It is always advisable that local administrators from district levels should work with local Government so that service up gradation, proper availability of the services can be noticed.

\subsection{Transparency and Accountability}

Officials and civil servants have responsibility to organize and consult all events related with lands. These steps aim to reduce corruption, stop cheap land release which helps urban poor. They also make sure about clear inclusive and accessible systems for exchanging land rights and legal security of term. Setting up codes of conduct, promoting an ethic of facility to the public by putting into place adequate compensation for public servants, creating public feedback mechanisms, providing access to information (on land (management)) etc aimed to be improved.

\subsection{Other Approaches in Coping with Informal Land Delivery System in Cities}

With time number of informal land occupation/ acquisition, informal land tenure systems, informal land transfers, and persons associated with this has been changed. In the 1960s, it has been recognized that secure term leads to self-help actions of squatters (Doebele 1983).

According to Mertins et al (1998) and Ward (1998), substantial improvement and incorporation of informal agreements in urban has become a common practice. Site and service projects, apart from land pooling and land readjustment have become well-liked precautionary initiatives. As it is expensive, hence absent of their objective groups, recent initiatives offer sites without services.

According to Durand-Lasserve (1996), impersonate dissentient steps followed in an inverted array of urban development where profession antecede planning, servicing and construction. Cameroon and Rwanda introduced another remedial initiative - "guided development" quite alike with former site-and-service projects. It combines informal actors such as traditional chiefs, sub-dividers and land developers. Along with emulating, dissentient forms of land management, countries gradually combine more into its formal systems. Traditional regular rights also fit here. As per Fourie 1998; Mertins et al 1998 and Kiamba 1998, lands need to sell through society commissions. Technique to lessen land market actions is the restraint of the size of individual plots to diminish the attention of the middle class to devote. The last initiative needs stringent control-measures to shun that people buy numerous sites linked to each other. All these above mentioned steps try to shun settler to sell their shacks. Proper combination of both these channels can be a solution. For implementing this idea agreement between and informal (non-conform) land management bicker, as well as state and local communities is needed (Kombe and Kreibich, 2000). Many similarities exist with Tanzania. Land management process is initially strong in the starting phases. Along with more demand for making land, saturated settlements are losing its influence.

\section{Methodology}

It is mostly a tasking venture in collecting data for research especially in most of our traditional Nigeria cities. The scenario is much more pronounced when embarking on study with little or no record base like informal land channel. Hence, to achieve our objectives, primary data were relied upon largely and a few document reviews of data from previous research collected from five of the Karu urban districts such as New Karu, Mararaba, Masaka, New Nyanya, and Ado. To achieve this, purposive sampling Technique was utilised for this research. All householders were eligible to answer the survey questionnaire; a sample size of 0.25 percent was adopted from the five districts of Karu Urban Area which gives an approximated value of 310 respondents used for the study. The sample size was arrived at using Taro Yemane formula. According to Yamene, the sample size of 0.1-.05 is recommended for carrying out research depending on the size of your sample frame. Hence, having a sample frame of 124,043 the sample size of 0.25 that falls within the recommended sample size was adopted. These 310 respondents were spread across the five districts of Karu Urban Area. The questions related to strategies to improve informal land delivery process were drawn and administered in order to ascertain the level of their viability in Informal Land access on each stratum, by large the entire city. This is summarized in the table below:

\begin{tabular}{|c|c|c|c|}
\hline Districts & $\begin{array}{c}\text { Projected } \\
\text { Population }\end{array}$ & $\begin{array}{c}\text { Household } \\
\text { Population }\end{array}$ & $\begin{array}{c}\text { Sample Size (\%) } \\
\text { (No of Respondents - Household } \\
\text { Owners) }\end{array}$ \\
\hline Mararaba & 195,994 & 32,666 & 82 \\
\hline Kuruduma & 142,306 & 23,718 & 59 \\
\hline New Karu & 166,573 & 27,762 & 69 \\
\hline Ado & 70,050 & 11,675 & 29 \\
\hline Masaka & 169,333 & 28,222 & 71 \\
\hline Total & 744,256 & 124,043 & 310 \\
\hline
\end{tabular}

Table 1: Sample Distribution for Household Home Owners

Source: Authors Field work, 2016 


\section{Results and Discussion}

\subsection{The Necessary Strategies to Make Informal Land Delivery Process More Efficient}

Having taken stock of the various dimensions of urban land informality, this research has however proposed five coordinated strategies as reviewed from the literature in terms of dealing with informal land delivery these are: Guided development, partnership/ cooperation with actors in the informal land delivery sector, introduction of local land administrators, land regularisation and assessment. A combination of these three strategies seeks to achieve efficient and effective informal land management process, in Nigeria and Africa in general. However, to test the feasibility and ascertain the acceptability of these strategies, this study decided to sample the opinions of various stakeholders involve in informal land activities in Karu Urban Area using the Likert scale. These strategies are discussed below:

\subsection{Guided Development}

The level of acceptability of this strategy is shown in Table 2 seeing that $61.6 \%$ of respondents strongly agreed to this assertion that informal stakeholders should be part of formal institution. This method reveals that apart from operating informally in dealing with land management, countries are comprehensively integrating them into their formal mechanism, while $34.5 \%$ also agreed. However, $1.6 \%$ and $2.3 \%$ of the respondents opposed this assertion. Therefore, going by the outcome of these responses, this strategy is well accepted to improving informal land delivery because of its strong disposition to promoting tenure security of land ownership

\begin{tabular}{|c|c|c|c|c|c|c|c|}
\hline & New Karu & Kuruduma & Masaka & Mararaba & Ado & & \\
\hline & $\begin{array}{c}\text { No. } \\
\text { of Response }\end{array}$ & $\begin{array}{c}\text { No. } \\
\text { of Response }\end{array}$ & $\begin{array}{c}\text { No. } \\
\text { of Response }\end{array}$ & $\begin{array}{c}\text { No. } \\
\text { of Response }\end{array}$ & $\begin{array}{c}\text { No. } \\
\text { of Response }\end{array}$ & Total & $\%$ \\
\hline Responses & & & & & & & \\
\hline $\begin{array}{c}\text { Strongly } \\
\text { disagree }\end{array}$ & - & 3 & 1 & 1 & - & 5 & 1.6 \\
\hline Disagree & 1 & 2 & 3 & - & 1 & 7 & 2.3 \\
\hline Agree & 20 & 18 & 29 & 33 & 7 & 107 & 34.5 \\
\hline $\begin{array}{c}\text { Strongly } \\
\text { agree }\end{array}$ & 48 & 36 & 38 & 48 & 21 & 191 & 61.6 \\
\hline Total & 69 & 59 & 71 & 82 & 29 & 310 & 100 \\
\hline
\end{tabular}

Table 2: Guided Development

Source: Author's Computation, 2016

\subsection{Transparency and Accountability}

This strategy seeks to ensure that administrative and procedural incentives for corruption are thoroughly minimized. All measures that improve transparency such as establishing codes of conduct, promoting ethic of service to the public by creating public feedback mechanisms, providing access to information on land management and the like. The feasibility of this strategy is however depicted in Table 3 below where it shows that $46.5 \%$ strongly agreed that "Transparency and Accountability" is an effective strategy in improving informal land delivery process in Karu Urban Area and this was supported by $33.9 \%$ respondents who agreed with the position. Only $8.7 \%$ of the respondents however disagreed and $10.9 \%$ of the respondents were against this position.

\begin{tabular}{|c|c|c|c|c|c|c|c|}
\hline & New Karu & Kuruduma & Masaka & Mararaba & Ado & & \\
\hline & $\begin{array}{c}\text { No. } \\
\text { of } \\
\text { Response }\end{array}$ & $\begin{array}{c}\text { No. } \\
\text { of Response }\end{array}$ & $\begin{array}{c}\text { No. } \\
\text { of } \\
\text { Response }\end{array}$ & $\begin{array}{c}\text { No. } \\
\text { of Response }\end{array}$ & $\begin{array}{c}\text { No. } \\
\text { of } \\
\text { Response }\end{array}$ & Total & $\%$ \\
\hline Responses & & 5 & 9 & 10 & - & 27 & 8.7 \\
\hline $\begin{array}{c}\text { Strongly } \\
\text { disagree }\end{array}$ & 3 & 6 & 10 & 9 & 2 & 34 & 10.9 \\
\hline Disagree & 7 & 6 & 22 & 29 & 9 & 105 & 33.9 \\
\hline Agree & 25 & 20 & 30 & 34 & 18 & 144 & 46.5 \\
\hline Strongly agree & 34 & 28 & 71 & 82 & 29 & 310 & 100 \\
\hline Total & 69 & 59 & 71 & & & & \\
\hline
\end{tabular}

Table 3: Transparency and Accountability

Source: Author's Computation, 2016

\subsection{Recognition}

Mode of operation of urban informal land delivery channels in policy, law and organizational environment, is the main purpose of reorganization. Important postures are being expected from land administrators on these parameters. Rather than becoming hindrance, legal, policy and institutional scopes act as a backbone for any procedures within their donjon.

To ascertain the feasibility of this strategy Table 4 below shows that $57.1 \%$ strongly agreed that Legal Recognition informal land delivery sector is a necessary strategy that will improve informal land delivery process in Karu Urban Area 
and this was supported by $36.2 \%$ respondents who also agreed with this assertion. However, $1.9 \%$ of the respondents disagreed while $4.8 \%$ of the respondents were also against this position.

\begin{tabular}{|c|c|c|c|c|c|c|c|}
\hline & New Karu & Kuruduma & Masaka & Mararaba & Ado & & \\
\hline & $\begin{array}{c}\text { No. } \\
\text { of Response }\end{array}$ & $\begin{array}{c}\text { No. } \\
\text { of Response }\end{array}$ & $\begin{array}{c}\text { No. } \\
\text { of Response }\end{array}$ & $\begin{array}{c}\text { No. } \\
\text { of Response }\end{array}$ & $\begin{array}{c}\text { No. } \\
\text { of Response }\end{array}$ & Total & $\%$ \\
\hline Responses & & 2 & - & 4 & - & 6 & 1.9 \\
\hline $\begin{array}{c}\text { Strongly } \\
\text { disagree }\end{array}$ & - & 3 & 2 & 4 & 3 & 15 & 4.8 \\
\hline Disagree & 3 & 23 & 27 & 35 & 9 & 112 & 36.2 \\
\hline Agree & 18 & 31 & 42 & 39 & 17 & 177 & 57.1 \\
\hline Strongly agree & 48 & 59 & 71 & 82 & 29 & 310 & 100 \\
\hline Total & 69 & 59 & & & & & \\
\hline
\end{tabular}

Table 4: Recognition

Source: Author's Computation, 2016

\subsection{Introduction of Local Land Managers at District Levels}

This strategy becomes necessary for managing informal land delivery challenges at the local level. A prerequisite for this would be good social skills and technical capacity as well as access to information concerning the range of issues that affect land delivery and sustainability

Table 5 shows the feasibility level of this strategy via the outcome of responses received from the questionnaires. Hence, $60.9 \%$ strongly agreed that Partnership and cooperation with actors in the informal land delivery sector is a necessary strategy that will improve informal land delivery process while $31.3 \%$ respondents who also agreed with this assertion. Nevertheless, 3.3\% of the respondents disagreed as well as $4.5 \%$ of the respondents who also strongly disagreed with this notion.

\begin{tabular}{|c|c|c|c|c|c|c|c|}
\hline & New Karu & Kuruduma & Masaka & Mararaba & Ado & & \\
\hline $\begin{array}{c}\text { No. } \\
\text { of Response }\end{array}$ & $\begin{array}{c}\text { No. } \\
\text { of Response }\end{array}$ & $\begin{array}{c}\text { No. } \\
\text { of Response }\end{array}$ & $\begin{array}{c}\text { No. } \\
\text { of Response }\end{array}$ & $\begin{array}{c}\text { No. } \\
\text { of Response }\end{array}$ & Total & $\%$ \\
\hline Responses & & - & 2 & 6 & 1 & 10 & 3.3 \\
\hline $\begin{array}{c}\text { Strongly } \\
\text { disagree }\end{array}$ & 1 & 1 & 3 & 7 & - & 14 & 4.5 \\
\hline Disagree & 3 & 17 & 22 & 31 & 7 & 97 & 31.3 \\
\hline Agree & 20 & 41 & 44 & 38 & 21 & 189 & 60.9 \\
\hline $\begin{array}{c}\text { Strongly } \\
\text { agree }\end{array}$ & 45 & 59 & 71 & 82 & 29 & 310 & 100 \\
\hline Total & 69 & 59 & & & & & \\
\hline
\end{tabular}

Table 5: Introduction of Local Land Managers at District Levels

Source: Author's Computation, 2016

\subsection{Assessment}

Informal land delivery channels related transparent scenario can be visualized by land administrators from this. Moreover it provides an idea about legal, policy and institutional dimensions and expectations from these. These practices make a land controller more enhanced with an indication to adopt proactive / anticipatory measures as well as remedial measures.

Table 6 shows the feasibility level of this strategy via the outcome of responses received from the questionnaires. Hence, $60.9 \%$ strongly agreed that Assessment of the informal land delivery sector is necessary strategy that will improve land delivery process while $31.3 \%$ respondents who also agreed with this assertion. Nevertheless, $3.3 \%$ of the respondents disagreed as well as $4.5 \%$ of the respondents who also strongly disagreed with this notion.

\begin{tabular}{|c|c|c|c|c|c|c|c|}
\hline & New Karu & Kuruduma & Masaka & Mararaba & Ado & & \\
\hline & $\begin{array}{c}\text { No. } \\
\text { of Response }\end{array}$ & $\begin{array}{c}\text { No. } \\
\text { of Response }\end{array}$ & $\begin{array}{c}\text { No. } \\
\text { of Response }\end{array}$ & $\begin{array}{c}\text { No. } \\
\text { of Response }\end{array}$ & $\begin{array}{c}\text { No. } \\
\text { of Response }\end{array}$ & Total & $\%$ \\
\hline Responses & & 3 & 7 & 11 & 1 & 27 & 8.7 \\
\hline $\begin{array}{c}\text { Strongly } \\
\text { disagree }\end{array}$ & 5 & 4 & 9 & 6 & - & 22 & 7.1 \\
\hline Disagree & 3 & 22 & 25 & 31 & 12 & 108 & 34.8 \\
\hline Agree & 18 & 30 & 30 & 34 & 16 & 153 & 49.4 \\
\hline $\begin{array}{c}\text { Strongly } \\
\text { agree }\end{array}$ & 43 & 59 & 71 & 82 & 29 & 310 & 100 \\
\hline Total & 69 & & & & & & \\
\hline
\end{tabular}

Table 6: Assessment

Source: Author's Computation, 2016 


\section{Summary}

From our discussion above, it reveals that "guided Development" is a necessary strategy for the efficient operation of informal land delivery in Karu Urban Area. In the scale of acceptability and feasibility of all the strategies proposed, this strategy has the highest percentage where about $96.1 \%$ of the respondents attested to this proposition. This might be as a result of its strong disposition to promoting tenure security of land ownership, Lasserve (1996). This is closely followed by "Legal Recognition" of the informal land delivery sector where 93.3\% of the respondents also concurred with assertion. This might not also be unconnected with the fact that this strategy has the capacity to stimulate and enhance community inclusiveness and social coherence in the urban setting via the integration of informal land management in the formal provision of land and services; and integration of informal institutions settling or mediating land conflicts at the sub-urban level. However, the next strategy on the scale of feasibility by the respondent is the "Introduction of Local Land Managers at District Levels" where $92.2 \%$ of the respondents are inclined to this position as against $7.8 \%$. The proponent of this strategy believes that the strategy has the capacity to refine the operation of the informal land delivery and in a way add value to its operation for mutual relationship that will dual system of land delivery in our cities, Adamu (2014). "Assessment" of informal land delivery process attracts $81.2 \%$ of the respondents. This approach would make sureto hierarchize of probable dealings to take and would put the informal land actors in an improved place to decide when to act proactively, taken counteractive exploit or to be imprudent, Gondo, (2008). About $80.4 \%$ of the respondent also believed that "Transparency and Accountability" as a strategy will improve informal land delivery as against 19.6\% who thing otherwise. The respondents acknowledge this strategy to be capable of handling corruption tendency in land delivery and transfer of rights.

Therefore, from the foregoing, we can deduce that all the strategies have high level of acceptability depending on their level of importance as understood by the respondents.

\section{Conclusion}

To develop an effective urban land via the informal mechanism, strategies that facilitates and support participation of all irrespective of social and economic class must be fully appreciated. These strategic interventions must as well recognise the different actors in the informal land sector. This therefore, calls for a shift in how policy makers conceptualise the regulation of urban land institution. There is a need to move from the traditional norms which is fast becoming inefficient in meeting the demand for land in our urban settings. In other words, state should not be seen as the sole umpire in charge of controlling urban land markets but alternative institutions, in this case, formal and informal be allowed manage and regulate urban land market to be supported by law. The critical challenge remains how to develop the appropriate mechanisms to do this in ways that will benefit the majority of urban dwellers

\section{References}

i. Adamu, D. (2014). Appraisal of the urban management challenge of informal land delivery in Karu urban area . Zaria, Nigeria: Unpublished M.Sc. URP Thesis, Ahmadu Bello University.

ii. Al-sayyad. et al (2000) „Land Title Registration and Security of Tenure in Mozambique“, Development, Journal of Environment and Urbanisation, pp.100-115

iii. Antwi, A. (2002). A Study of Informal Urban Land Transactions in Accra, Ghana. Accra, Ghana: RICS Foundation.

iv. Faurie. C. (1997) „Combining Informal Systems with Formal Systems - The Challenge Facing Land Managers". UnHabitat Debate, Vol. 3, No. 2, June 1997 pp.7-11

v. Carlsson. L. et al (2005) „Co-management: Concepts and Methodological Implications". Journal of Environmental Management pp65-76

vi. Doebele. W.A (1983) „The Provision of Land for the Urban Poor: Concepts, Instruments and Prospects: Land for Housing the Poor". Asian Economic Summit, Bangkok 1983, pp 348-374

vii. Danladi, A. A. (2016). Appraisal of Informal Access to land for Housing delivery in Karu area of Nasarawa State. Minna, Nigeria: Unpublished M.Tech. URP Thesis, Federal University of Science and Technology.

viii. Durand L. A (1996) „Regularization and Integration of Irregular Settlements: Lessons from Experience“. UNDP/ UNCHS/ World Bank - Urban Management Programme UMP Working Paper, Kenya. Pp 5-7

ix. Durand L. A (2001) „Current Changes and Trends in Sub-Saharan Francophone African Countries with Particular Emphasis on Benin, Burkina Faso, and Senega". Tenure Project Workshop, London, pp.16 - 19

x. Kiamba. C. (1998) „Urban Land Market Reform in Kenya - Issues, Perspectives and Challenges": UNDP/ UNCHS/ World Bank - Urban Management Programme UMP Working Paper, Kenya. Pp 18-22

xi. Kiamba. C. (1998) „Comparative Policy Perspectives on Urban Land Market Reform in Latin America, Southern Africa and Eastern Europe" Lincoln Institute of Land Policy Boston, Vol. 3, No. 2, June 1997 pp.17-19

xii. Kironde, J. M. (1995). Access to land by the urban poor in Tanzania: some findings from Dar es Salaam. Environment and Urbanization, 7(1), 77-96.

xiii. McAuslan. P (2001) „Non-statutory Security of Tenure and Law: The Legality of Illegality and the Illegality of legality". Tenure Project Workshop London.pp2-7

xiv. Mertins. G et.al (1998) „Land Tenure and Land Regularization in Informal Urban Settlements in Developing Countries-examples from Lating America and Africa". Environment and Urbanization, Vol. 7, No. 1, April 1995. Pp 3-7

xv. Natcher. D. C et.al (2005) Co-Management: Managing Relationships, not Resources. Human Organization 64(3): pp-240-250 
xvi. Perera. R (1994) „Accommodating Informality: A Transnational Perspective“. Unpublished Manuscripts. Crossing Boarders Initiative, pp8

xvii. Thirkell A. J. (1996) Players in urban informal land markets: A case study of Cebu City,International Journal of Environment and Urbanization, Vol. 8(2), 71-90

xviii. UN-Habitat. (2010). Urban Land Markets: Economic Concepts and Tools for Engaging in Africa. Kenya: UN-Habitat.

xix. Gondo, T. (2008). Urban land and informality: An evaluation of institutional response options to land informalization in Ethiopian cities. Department of Urban and Regional Planning, University of Venda, Limpopo Province, South Africa.

xx. Ward. P (1998) „International Forum on Regularization and Land Markets". Newsletter of the Lincoln Institute of Land Policy, vol.10 pp1-4

xxi. Wehrmann B (2002) „Coping with Informal Land Management in Human Settlements: an Overview of the Status Quo". Environment and Urbanization, Vol. 7, No. 1, April 1995. Pp13-14 